Wydanie w otwartym dostępie na licencji CC BY-NC-ND

This is an open access article under the CC BY-NC-ND license

Mateusz Bartoszewicz orcid.org/0000-0002-4988-9934

Uniwersytet Wrocławski

mateusz.bartoszewicz@uwr.edu.pl

Filip Gołębiewski (D) orcid.org/0000-0002-8562-0035

Instytut Dyskursu i Dialogu

Szkoła Doktorska Nauk Społecznych Academia Rerum Socialium UMK w Toruniu

filip.a.golebiewski@gmail.com

\title{
PARADOKS OPŁACALNOŚCI. STRONNICZOŚĆ POLITYCZNA NA POLSKIM RYNKU MEDIALNYM - PRÓBA SYNTEZY
}

\section{Abstract \\ THE PROFITABILITY PARADOX. POLITICAL BIAS ON THE POLISH MEDIA MARKET - AN ATTEMPT OF A SYNTHESIS}

The study includes an attempt to synthesize the basic trends of political bias of 14 relevant media entities appearing on the Polish media market in a context of their readership and viewership. Searching for an intersubjectively consistent analytical perspective, the authors use critical and comparative analysis of the results of empirical research contained in the literature of the subject, as well as the content of specialized institutional reports, with a respect to the methods of critique of sources. Due to the processual nature of the development of the media market in Poland, some of the results of empirical research cited goes back to year 2010 but the vast majority concerns year 2015 and the next ones. In the introduction, the authors refer to the universal agreement of researchers of the quality of Polish public debate regarding its critical assessment. The first section of the article contains a description of the methodological assumptions made. The next three contain an attempt to synthesize the basic bias trends of relevant media titles within each of the three segments of media activity: [1] the press sector of nationwide dailies; [2] the weekly sector of opinion-forming magazines; and [3] the 24-hour news television sector. The last part of the study contains conclusions and reference to the research results of the political parallelism concept.

Keywords: media bias, political parallelism, Polish public debate, journalism, managing the media system 


\section{Wprowadzenie (wstęp i tło teoretyczne)}

W klasycznej już pracy Systemy medialne. Trzy modele mediów i polityki w ujęciu porównawczym Paolo Mancini i Daniel Hallin (2007) wyróżnili model spolaryzowanego pluralizmu, zwany również śródziemnomorskim. Mimo że w pierwotnym zamyśle autorów miał on odnosić się do krajów południa Europy, część badaczy (Dobek-Ostrowska, 2011a; 2011b, s. 49; Dobek-Ostrowska, 2015, s. 37-39; Nierenberg, 2011, s. 61) od lat uznaje go za adekwatny do opisu polskiego systemu medialnego:

Współczesny [2007-2010] rynek polskich mediów charakteryzuje się wysokim stopniem paralelizmu politycznego, odnoszącego się nie tylko do mediów publicznych. Także rola państwa w systemie medialnym wydaje się być znacząca. To sprawia, że nasz system medialny, wedle kryteriów zaproponowanych przez Hallina i Manciniego, należałoby zaliczyć do modelu spolaryzowanego pluralizmu, charakterystycznego dla europejskich krajów śródziemnomorskich (Nierenberg, 2011, s. 61).

Bogusław Nierenberg (2011, s. 60) odnotowuje, że upolitycznienie mediów publicznych w latach 2007-2010 „osiągnęło niespotykany dotąd poziom”. Diagnoza ta została przedstawiona na długo przed późniejszymi wydarzeniami polityczno-medialnymi, związanymi m.in. ze zwycięstwem obozu Zjednoczonej Prawicy w wyborach prezydenckich i parlamentarnych w roku 2015, jak również z następującymi po nich - kolejno - przejęciem i podporządkowaniem mediów publicznych przez środowiska związane ze zwycięską partią. Pisząc o „niespotykanym dotąd poziomie upolitycznienia mediów publicznych", Nierenberg prawdopodobnie nie spodziewał się wówczas, że skala upolitycznienia tak znacząco wzrośnie w kolejnych latach, doprowadzając do wykładniczego wzrostu poziomu polaryzacji debaty publicznej. Skutkowało to m.in. okresowym (2019) bojkotem anteny TVP przez przedstawicieli Platformy Obywatelskiej, jak również swego rodzaju „wojną medialną” na linii TVN24 i TVP Info (2020), w której wygaszenie zaangażowała się nawet ambasador Stanów Zjednoczonych w Polsce. Choćby tych kilka wymienionych problemów polskiego dyskursu politycznego prowokuje do powzięcia refleksji na temat przyczyn przemian, które zaszly przez ostatnie 10 lat w systemie medialnym w Polsce.

Niewiele długofalowych diagnoz dotyczących procesów społeczno-politycznych wywołuje wśród badaczy tak powszechną zgodę jak krytyczna ocena jakości polskiej debaty publicznej (Karwat, 2007, s. 14; Czyżewski, Kowalski, Piotrowski, 2010, s. 12; Furman, 2010, s. 56; Bobrowska, 2012, s. 39; Sanecka-Tyczyńska, 2015, s. 99; Bartoszek, 2018; Polkowska, 2018, s. 344). Fundamentalne spory o mit założycielski nowego państwa polskiego po 1989 roku, a także wypływające z nich różnice światopoglądowe stanowią podstawową płaszczyznę rywalizacji na scenie politycznej (Sanecka-Tyczyńska, 2015, s. 99). Bieżące spory i konflikty przebiegają nie tylko na poziomie komunikowania między indywidualnymi graczami medialnymi i politycznymi. Rywalizacja sięga o wiele głębiej - ma bowiem charakter międzydyskursywny (Bobrowska, 2012, s. 40). 
Odrębne uniwersa symboliczne $e^{1}$, zorganizowane wokół przeciwstawnych środowisk medialno-politycznych, w skrajnie odmienny sposób opisują rzeczywistość współczesną, jak i interpretacje historyczne, oceniając je na podstawie nieprzystających do siebie kryteriów (Bartoszewicz, 2019, s. 59-60; Obacz, 2018, s. 18-19). Z konkurencyjnymi względem siebie i rywalizującymi ze sobą uniwersami symbolicznymi (Bartoszewicz, 2019, s. 59-60) związani są przedstawiciele tożsamościowych elit symbolicznych (Mielczarek, 2018, s. 219). Różne uniwersa, oprócz piszących dlań autorów i dziennikarzy, „zasiedlają” z pozoru ci sami aktorzy życia politycznego, jednakże nadawane im atrybuty i sposoby dystrybucji znaczeń wyraźnie różnią się w zależności od uniwersum. Największe środowiska polityczne swoje wysokie poparcie społeczne zawdzięczają utrzymywaniu elektoratów w ciągłej mobilizacji i działaniu według zasady divide et impera. Wymaga to stałego wysyłania komunikatów przez kanały komunikacyjne powiązane z „zaprzyjaźnionymi” ośrodkami medialnymi.

Niniejszy tekst jest próbą przyjrzenia się temu zjawisku w sferze zarządzania mediami oraz zwrócenia uwagi na rynkowy aspekt skrajnej polaryzacji mediów połączonej z ich polityzacją w ciągu ostatniej dekady. Niewykluczone bowiem, że racjonalne podmioty, jakimi są główne (relewantne) media w Polsce, podejmując decyzje mające na celu radykalizację swoich przekazów, wykorzystują po prostu „niedoskonałości modelu” spolaryzowanego pluralizmu dla własnych, partykularnych celów. To zaś może prowadzić do postawienia tezy, że ów, wyróżniony przez Manciniego i Hallina, model systemowy prowadzi do paradoksalnej sytuacji, w której dziennikarstwo bezstronne, niezwiązane z politycznym zaangażowaniem redakcji (czyli po prostu etyczne), staje się nieopłacalne, a profity przynosi jego całkowite przeciwieństwo.

1 Ze względu na trwałą polaryzację polskiej sceny społeczno-politycznej i nieprzystające do siebie kryteria oceny podstawowych faktów życia społecznego, które stosowane są przez główne podmioty medialne i polityczne (by wymienić choćby diametralnie rozbieżne oceny wobec polityki tzw. grubej kreski, ocenę historii i działalności współczesnej Lecha Wałęsy czy kwestię praworządności), autorzy stawiają tezę, że w wypadku polskiej debaty publicznej można mówić o co najmniej dwóch współistniejących „uniwersach symbolicznych”. Wektory ich oddziaływań pod względem paralelizmu polityczno-medialnego są przeciwstawne, by nie powiedzieć - równoważące się wzajemnie. O pierwszym uniwersum można w uproszczeniu powiedzieć, że ma charakter konserwatywno-prosocjalny, bazujący na resentymencie „przegranych” transformacji ustrojowej. O drugim zaś, że charakteryzuje się nastawieniem progresywistyczno-liberalnym i bazuje na ambicjach „wygranych” transformacji oraz dążeniu do „dostosowania się” do wymogów liberalnie rozumianej Unii Europejskiej lub silnej motywacji części społeczeństwa, aby dołączyć do owych „wygranych”. Języki, narracje i „światy fabularne” tworzone i podtrzymywane na łamach dominujących mediów (by wymienić choćby TVP Info i TVN24) - w tym także społecznościowych - są oparte na przeciwstawnych dychotomiach, a stosowane „słowniki” języków politycznego i ekonomicznego są skrajnie różne, często nawet sprzeczne ze sobą. Różne na tyle, że - w opinii autorów - stanowiące inne uniwersa, pośród których dopiero zachodzi rywalizacja. Tytułem przykładu - „Gazeta Polska” nie rywalizuje o czytelnika z tygodnikiem „Polityka”. „GP” rywalizuje z tygodnikiem „Sieci”, a „Polityka” z czasopismem „Newsweek Polska” lub z „Gazetą Wyborczą”. 
Autorzy opracowania postanowili podjąć próbę syntetyzującego ujęcia podstawowych kierunków stronniczości politycznej występujących na polskim rynku medialnym oraz porównać je z poziomem czytelnictwa/oglądalności/wpływu/sprzedaży analizowanych mediów. Ten etap analityczny służy uzasadnieniu tezy zawartej w tytule niniejszego artykułu, wskazującej na paradoks opłacalności dziennikarstwa stronniczego, wyraźnie zaangażowanego na płaszczyźnie politycznej. Pierwsza część opracowania zawiera opis przyjętych założeń metodologicznych. Kolejne trzy zawierają próbę syntezy podstawowych kierunków stronniczości wybranych tytułów medialnych w [1] sektorze ogólnopolskich dzienników („Gazeta Wyborcza” [„GW”], „Rzeczpospolita” [„Rz”], „Gazeta Polska Codziennie” [„GPC”], „Fakt” oraz „Super Express” [„SE”]); [2] sektorze tygodników opinii („Polityka”, „Wprost”, „Newsweek Polska”, „Sieci”, „Do Rzeczy” oraz „Gazeta Polska” [„GP”]); [3] sektorze całodobowych stacji informacyjnych (TVP Info, TVN24, Polsat News). Ostatnia część opracowania zawiera konkluzje.

\section{Założenia metodologiczne}

Przyjęcie systemowej optyki rozpatrywania problemu tytułowego „paradoksu opłacalności” dla dziennikarstwa stronniczego stanowiło asumpt do postawienia następującej hipotezy roboczej: w polskiej debacie publicznej², pośród spektrum podmiotów relewantnych medialnie ${ }^{3}$, wyraźnie dominują takie, w których przekazie występuje wysoki stopień stronniczości politycznej ${ }^{5}$. Na etapie projektowania badania zdecydowano się na wybór od trzech do sześciu podmiotów dominujących w obrębie każdego z trzech segmentów działalności medialnej: [1] prasowego sektora dzienników ogólnopolskich; [2] sektora tygodników opinii o profilu społeczno-politycznym; a także [3] sektora całodobo-

2 Debatę publiczną zdefiniowano jako dyskusję na ważny temat, dotyczący całego społeczeństwa lub pokaźnej zbiorowości, który powoduje kontrowersje i spory. Można ją analizować zarówno w kategoriach jednostkowych wydarzeń dyskursywnych, jak i w sposób procesualny (Kampka, 2014, s. 17-18).

3 Podmiot relewantny medialnie to taki, którego wpływ na przebieg debaty publicznej jest znaczny. Relewantność poszczególnych aktorów medialnych, czyli poziom ich istotności lub ważności, można intersubiektywnie mierzyć za pomocą wskaźników takich jak: średni nakład jednorazowy, rozpowszechnianie płatne razem, oglądalność i opiniotwórczość.

4 Wyraźna dominacja na potrzeby niniejszego opracowania została zdefiniowana jako taki stosunek liczby podmiotów o wysokim stopniu stronniczości do wszystkich podmiotów poddawanych analizie, którego wartość wyniosłaby co najmniej 75\%. Relewantnych podmiotów poddawanych analizie jest 14, zatem warunkiem pozytywnej weryfikacji hipotezy będzie uzyskanie liczby co najmniej 11 podmiotów o wysokim stopniu stronniczości.

W literaturze przedmiotu wyróżnia się stronniczość niezamierzoną oraz stronniczość zamierzoną (Klepka, 2018, s. 191). Autorzy niniejszego opracowania zajmują się przede wszystkim tą drugą. 
wych telewizji informacyjnych. Finalnie wybrano czternaście takich podmiotów. $\mathrm{Na}$ podstawie treści komunikatu Związku Kontroli Dystrybucji Prasy (ZKDP) o wysokości nakładów i dystrybucji tytułów w roku 2018 uszeregowano tytuły prasy codziennej pod względem wartości wskaźnika „rozpowszechniania płatnego razem" (dalej: r.p.r.).

Z grona dzienników wyselekcjonowano pięć redakcji ogólnopolskich z najwyższym poziomem r.p.r. Były to kolejno: „Fakt” (237 700 r.p.r.), „SE” (118 370), „GW” (106 227), „Rz” (45 108) oraz „GPC” (15 388). Z zestawienia wykluczono wszystkie dzienniki regionalne oraz „Dziennik Gazetę Prawną” (41 366 r.p.r.) ze względu na jej specjalistyczny, prawniczo-ekonomiczny charakter. Warto nadmienić, iż prawie wszystkie wymienione dzienniki (oprócz „GPC”) znalazły się w ścisłej czołówce rankingu najbardziej opiniotwórczych tytułów prasowych roku 2018, opracowanego przez Instytut Monitorowania Mediów (IMM). Jak czytamy w raporcie - „Rz” osiągnęła wynik 23873 cytowań, „GW” - 18 815, „Fakt” - 12 888, tymczasem „SE”- 12543.

Do selekcji tygodników opinii zastosowano podobny mechanizm, uzupełniając go o drugi etap wyboru, zależny od wskaźników opiniotwórczości. Na podstawie komunikatu ZKDP wyselekcjonowano osiem tygodników opinii o profilu społeczno-politycznym z największym poziomem r.p.r. Były to kolejno: „Gość Niedzielny” (112 660), „Polityka” (97 466), „Wprost” (85 825), „Newsweek Polska” (85 306), „Sieci” (44 216), „Do Rzeczy” (43 444), „Tygodnik Powszechny” (27 239), „Gazeta Polska” (26 870).

Tabela 1. Relewantne podmioty prasowe na polskim rynku medialnym

\begin{tabular}{|c|c|c|c|c|c|}
\hline \multicolumn{3}{|c|}{ Dzienniki ogólnopolskie } & \multicolumn{3}{|c|}{ Tygodniki opinii o profilu społeczno-politycznym } \\
\hline Tytuł & r.p.r. (2018) & $\begin{array}{c}\text { Cytowania } \\
\text { (2018) }\end{array}$ & Tytuł & r.p.r. (2018) & $\begin{array}{c}\text { Cytowania } \\
(2018)\end{array}$ \\
\hline „Fakt” & 237700 & 12888 & „Polityka” & 97466 & brak danych \\
\hline $\begin{array}{l}\text { „Super } \\
\text { Express" }\end{array}$ & 118370 & 12543 & „Wprost” & 85825 & 2290 \\
\hline $\begin{array}{l}\text { „Gazeta } \\
\text { Wyborcza” }\end{array}$ & 106227 & 18815 & $\begin{array}{l}\text { „Newsweek } \\
\text { Polska” }\end{array}$ & 85306 & 2662 \\
\hline $\begin{array}{l}\text { „Rzeczpospo- } \\
\text { lita” }\end{array}$ & 45108 & 23873 & „Sieci” & 44216 & 2907 \\
\hline $\begin{array}{l}\text { "Gazeta Polska } \\
\text { Codziennie" }\end{array}$ & 15388 & brak danych & „Do Rzeczy” & 43444 & 3030 \\
\hline- & - & - & $\begin{array}{l}\text { "Gazeta } \\
\text { Polska" }\end{array}$ & 26870 & 2539 \\
\hline
\end{tabular}

Źródło: opracowanie własne na podstawie komunikatu ZKDP o wysokości nakładów i dystrybucji tytułów w roku 2018 oraz raportu IMM za rok 2018. 
Ze względu na celowy dobór próby badawczej i tytułów poddawanych dalszym analizom na podstawie danych IMM zawężono liczbę tytułów z ośmiu do sześciu. $\mathrm{W}$ przypadku pięciu $\mathrm{z}$ nich decyzję podjęto na podstawie pozycji rankingowych w raporcie IMM. Pomimo że w roku 2018 tygodnik „Polityka” nie wystąpił na wysokiej pozycji w analizowanym zestawieniu opiniotwórczości, to jednak ze względu na wysoką wartość współczynnika r.p.r., a także stricte polityczny charakter zawartości autorzy postanowili włączyć ten periodyk do analiz . Do dalszych badań wybrano zatem następujące tygodniki: „Do Rzeczy” (3030 cytowań według raportu IMM), „Sieci” (2907), „Newsweek Polska” (2662), „Gazeta Polska” (2539), „Wprost” (2290) oraz „Polityka”.

Przy selekcji całodobowych stacji telewizyjnych zdecydowano się na uwzględnienie trzech największych i najbardziej opiniotwórczych nadawców według raportu IMM. Mowa o publicznej TVP Info (11 732 cytowań), a także prywatnych TVN24 (25 624) i Polsat News (8355).

Wszystkie powyższe podmioty zostały w kolejnych podrozdziałach przeanalizowane pod kątem występowania różnic dyskursywnych związanych ze stosowaniem praktyk stronniczości politycznej (Dobek-Ostrowska, 2011a, s. 69-78). Sama kategoria stronniczości została przez autorów zdefiniowana operacyjnie jako „faworyzowanie i wzmacnianie, $z$ drugiej [strony - przyp. M.B.] zaś krytykowanie i osłabianie stanowiska (poglądów) lub któregoś z uczestników życia politycznego" (Dobek-Ostrowska, 2011a, s. 70). Badanie zostało przeprowadzone na podstawie syntetyzującego przeglądu wyników analiz empirycznych autorstwa różnych badaczy i organizacji zajmujących się kwestiami jakości debaty publicznej.

Poszukując intersubiektywnie zgodnej perspektywy analitycznej wobec nakreślenia podstawowych kierunków stronniczości wybranych mediów, posłużono się analizą krytyczną wyników badań empirycznych zawartych w literaturze przedmiotu, jak i treści specjalistycznych raportów instytucjonalnych. Wykorzystano informacje zawarte w raportach opracowanych na zlecenie instytucji takich jak: Biuro Instytucji Demokratycznych i Praw Człowieka (ODIHR) Organizacji Bezpieczeństwa i Współpracy w Europie, Krajowa Rada Radiofonii i Telewizji (KRRiT), Instytut Dziennikarstwa i Komunikacji Społecznej Uniwersytetu Papieskiego Jana Pawła II w Krakowie, Instytut Dyskursu i Dialogu, Fundacja im. Stefana Batorego, Instytut Bronisława Komorowskiego (IBK).

$\mathrm{Z}$ uwagi na procesualny charakter rozwoju rynku medialnego w Polsce część przytaczanych wyników badań empirycznych sięga roku 2010, jednakże zdecydowana większość dotyczy roku 2015 i okresu późniejszego. Ostatnie wykorzystane

6 Tygodnik „Gość Niedzielny” nie został włączony do analiz, ponieważ - ze względu na funkcjonującą od lat formę wydawnictwa w ramach współpracy z Kurią Metropolitalną w Katowicach dysponuje odrębną, wysoce rozwiniętą, wewnątrzkościelną siecią dystrybucji i promocji w skali całej Polski. Tym samym, w opinii autorów, jako podmiot związany z Kościołem katolickim stanowi przykład prasy religijnej (w pewnym sensie branżowej) o charakterze opiniotwórczym. Wszystkie inne analizowane tytuły mają wydawnictwa funkcjonujące $\mathrm{w}$ formule świeckiej. 
raporty pochodzą z pierwszej połowy roku 2020. Wybór lat 2010-2020 podyktowany został, z jednej strony, dążeniem do wykorzystania możliwie jak najbardziej aktualnych źródeł, a z drugiej zaś faktem, iż w połowie tego okresu nastąpiła alternacja władzy pomiędzy koalicją PO-PSL (2007-2015) a obozem Zjednoczonej Prawicy skoncentrowanym wokół PiS (2015-).

Wobec treści raportów z badań dotyczących stronniczości podmiotów medialnych została zastosowana staranna krytyka źródeł. Wynikało to z charakteru niniejszej pracy, której jednym z celów dodatkowych było spojrzenie metapoziomowe na dostępne w Polsce źródła odnoszące się do stronniczości przekazów medialnych i zweryfikowanie - czy one same nie cechują się również stronniczością. Krytyka źródeł miała charakter przede wszystkim zewnętrzny, w pewnych momentach nawet biograficzny, pozwalający na głębsze zrozumienie strukturalnych uwarunkowań autorów lub instytucji opracowujących owe raporty (np. KRRiT albo IBK).

\section{Podstawowe kierunki stronniczości w dziennikach ogólnopolskich}

Analizę porównawczą rozpoczęto od pięciu dzienników ogólnopolskich: „GW”, „Rz”, „GPC”, „Faktu” oraz „SE”. Z przeprowadzonych przez Rafała Leśniczaka (2019, s. 121) badań dotyczących konstruowania wizerunku UE w okresie kryzysu migracyjnego wynika, iż treści publikowane w okresie przedwyborczym (2015) na łamach „GW” cechował nacisk na powinność niesienia pomocy „uchodźcom” - co pod względem dyskursywnym było zbieżne z ówczesną polityką informacyjną rządu Ewy Kopacz (tvn24.pl, 2015). Jednocześnie na łamach „GW” ukazywały się teksty krytyczne wobec ówczesnego, wspieranego przez PiS stanowiska państw Grupy Wyszehradzkiej (Kokot, 2015), którym zarzucano brak postawy solidarnej w obliczu kryzysu (Leśniczak, 2019, s. 126). Tymczasem dziennik „Rz” trudno jednoznacznie zaklasyfikować wyłącznie jako prasę eurosceptyczną albo proeuropejską; prouchodźczą albo antyuchodźczą (Leśniczak, 2019, s. 121):

(...) dane liczbowe w trzech badanych kategoriach [polityka Willkommenskultur, kwestie bezpieczeństwa i nacjonalizm - przyp. M.B.] objawiły odmienność oceny kryzysu migracyjnego i uchodźczego dokonanej przez „Rzeczpospolitą”. Proporcje liczby publikacji wspierających i kontestujących decyzję Angeli Merkel były zbliżone. (...) Dziennik zatem ukazywał racje zwolenników oraz racje oponentów polityki Willkommenskultur.

Analizy Pauliny Olechowskiej (2017) dotyczyły stopnia stronniczości polskich dzienników ogólnoinformacyjnych w maju i czerwcu 2017 roku ${ }^{7}$. Autorka przeana-

Korpus badawczy stanowiło 215 tekstów opublikowanych na łamach czterech dzienników ogólnoinformacyjnych, ukazujących się na przełomie maja i czerwca 2017 roku (Olechowska, 2017, s. 109). 
lizowała „Gazetę Polską Codziennie”, „Gazetę Wyborczą”, „Nasz Dziennik” („ND”) oraz „Rzeczpospolitą”. Uzyskane wyniki badań potwierdziły tezę o stronniczości i zaangażowaniu politycznym dzienników: „GPC” (na rzecz obozu Zjednoczonej Prawicy, szczególnie PiS), „ND” (jw.) i „GW” (zdecydowanie krytycznej wobec PiS i „obozu” prezydenta Andrzeja Dudy). Co ciekawe, podobnie jak w przypadku badań Leśniczaka na łamach „Rz” preferencje i sympatie nie zostały wyrażone wprost, a sam przekaz cechował się wyższą neutralnością polityczną i niższym stopniem stronniczości ideologicznej (Olechowska, 2017, s. 126).

Stronniczość polityczna konserwatywnego pod względem światopoglądowym środowiska „GPC” (wsparcie narracyjne dla PiS) i liberalnej światopoglądowo „GW” (wyraźna krytyka PiS) prezentuje klarowny przykład nieprzystających do siebie perspektyw dyskursywnych. Problem ów ma korzenie w jednoczesnym funkcjonowaniu dwóch przeciwstawnych metanarracji odnoszących się do procesów transformacji ustrojowej po „upadku komunizmu”. Te odmienne sposoby opisywania rzeczywistości można - za Ewą Bobrowską (2012, s. 41) - na potrzeby niniejszego opracowania określić dychotomicznie mianem: [1] głosu optymizmu ustrojowego oraz [2] ustrojowego pesymizmu.

Empirycznie weryfikowalny stosunek przedstawicieli redakcji „GW” do aktorów politycznych kontestujących „narrację optymistyczną”, czyli w szczególności do PiS, a następnie Zjednoczonej Prawicy, trafnie oddają wyniki badań autorstwa Tomasza Litwina (2016, s. 113):

[GW] Traktowała w omawianym okresie [2007-2015] to ugrupowanie polityczne [PiS] nie jako zwykłą partię opozycyjną, ale jako partię antysystemową, której dojście do władzy zagraża demokracji w Polsce, a jej program ekonomiczno-społeczny grozi zapaścią finansów publicznych. $\mathrm{W}$ związku z polaryzacją polityczną w Polsce takie stanowisko automatycznie zbliżało „GW” do PO.

Taką konkluzję potwierdzają wyniki badań empirycznych autorstwa Jarosława Kardasia (2018, s. 164), z których wynika, że w okresie blisko trzech miesięcy przed wyborami parlamentarnymi w 2011 roku „GW” w zdecydowanej większości artykułów przedstawiała $\mathrm{PO}$ w pozytywnym świetle, jednocześnie bardzo ostro krytykując PiS:

Dla publicystów tego dziennika to partia antysystemowa, która jest pewnym zagrożeniem dla polskiej demokracji. Dziennikarze w swych komentarzach często zwracali uwagę na to, że Jarosław Kaczyński ma zadatki na autorytarnego wodza, ponieważ nie znosi sprzeciwu i ceni sobie tylko osoby bezwzględnie wobec niego lojalne.

Za kolejne źródło informacji na temat poziomu stronniczości wybranych dzienników posłużyło sprawozdanie z krótkoterminowej misji obserwacji wyborów parlamentarnych z 13 października 2019 roku, przeprowadzonej przez Biuro Instytucji Demokratycznych i Praw Człowieka. Dokument zawiera raport z monitoringu polskich mediów w ostatnich 14 dniach kampanii wyborczej do Sejmu 
i Senatu RP ${ }^{8}$. Wśród analizowanych przez ODIHR OBWE (2020, s. 21) podmiotów znalazły się wszystkie wyselekcjonowane tytuły dzienników.

Podczas „ostatniej prostej” do wyborów parlamentarnych w roku 2019 aż w czterech na pięć analizowanych tytułów prezentowano wyraźne sympatie i antypatie polityczne. „GPC” otwarcie popierała zarówno rząd, jak i PiS, jednocześnie wykazując negatywne, krytyczne nastawienie wobec Koalicji Obywatelskiej. „GW” prezentowała wyraźnie krytyczne stanowisko zarówno wobec rządu, jak i PiS. W przypadku raportu ODIHR ponownie odnotowano względnie neutralny charakter przekazu na łamach „Rz”, która: „pisała z kolei w bardziej neutralnym tonie na temat dwóch głównych sił politycznych, przy czym bardziej krytycznie odnosiła się do KO, a przychylniej wobec Lewicy" (Raport ODIHR OBWE, 2020, s. 22). Oprócz tego „Fakt” prezentował stanowisko krytyczne wobec aktualnego rządu i PiS z jednoczesną aprobatą Koalicji Obywatelskiej, natomiast „SE” zdecydowanie wspierał rząd, traktując partię $\mathrm{PiS}$ i $\mathrm{KO}$ we względnie wyważony sposób (Raport ODIHR OBWE, 2020, s. 21) ${ }^{9}$.

Reasumując, zarówno z treści przywołanych publikacji naukowych, jak i najnowszego raportu ODIHR OBWE wynika, iż cztery na pięć analizowanych dzienników ogólnopolskich na przestrzeni ostatniej dekady cechowały się wyraźną stronniczością polityczną. Intrygująco prezentuje się przypadek „Rz”, która jako jedyna z pięciu analizowanych dzienników ogólnopolskich zachowywała w stosunku do różnych antagonizujących kwestii i największych graczy politycznych stosunek względnie wyważony.

\section{Podstawowe kierunki stronniczości w tygodnikach opinii o profilu społeczno-politycznym}

Rola, jaką w debacie publicznej odgrywają tygodniki opinii, wpisuje się w koncepcję collective action frames. Poprzez strategiczne kreowanie uniwersów symbolicznych limitują one przestrzeń i definiują kwestie będące przedmiotem dyskursu politycznego (Kolczyński, 2008, s. 173-177). Jak szacuje Tomasz Mielczarek (2018, s. 219), liczebność grupy publicystów związanych z tygodnikami opinii w skali całej Polski wynosi około tysiąca osób. Są to elity polskiego dziennikarstwa, z których część wywodzi się ze świata kultury, nauki, sztuki, a część ze świata polityki.

8 ODIHR OBWE monitorował treści emitowane w czasie najwyższej oglądalności w pięciu stacjach telewizyjnych (TVP1 i TVP Info, TVN, TVN24 i Polsat) oraz publikowanew pięciu dziennikach („Fakt”, „GPC”, „GW”, „Rz” i „SE”).

9 Dwa największe w Polsce tytuły prasy tabloidowej - „Fakt” i „Super Express” - nie są wolne od przekazu uproszczonego, skandalizującego (Lisowska-Magdziarz, 2013, s. 24-35) i stronniczego (Hordecki, Piontek, 2011, s. 57). 
Poziom stronniczości politycznej na łamach „Newsweeka”, „Polityki” i „Sieci" w okresie kampanii wyborczej do Sejmu i Senatu RP w 2015 roku analizował w swoich badaniach Rafał Klepka (2016, s. 164). Badacz wskazał, że:

„Newsweek” $\mathrm{i}$ „Polityka” publikowały w większości materiały z negatywnym przesłaniem na temat PiS-u, czyniąc w zasadzie cały swój przekaz głównie negatywnym, natomiast „W Sieci” w równym stopniu stawiał sobie za cel wartościować pozytywnie PiS, co negatywnie PO.

Zdaniem Klepki (2016, s. 165-166) przekaz dotyczący poszczególnych komitetów wyborczych na łamach tygodnika „Polityka” cechował się najniższym poziomem stronniczości. „Newsweek” prezentował stanowisko wysoce krytyczne wobec PiS, jednakże na jego łamach pojawiały się nielicznie zarówno negatywne publikacje dotyczące PO, neutralne o PiS, jak i ambiwalentne na temat PO. „Newsweek” neutralnie relacjonował kampanię Nowoczesnej, ale jednocześnie negatywnie i ambiwalentnie pisał o relacjach na linii PiS-PO. Przekaz tygodnika „W Sieci” charakteryzowało wyraźne wspieranie PiS, podczas gdy wszystkie materiały o innych komitetach (oprócz Kukiz'15) na łamach tego magazynu cechowały się negatywizmem.

Zbieżne wyniki badań zaprezentowane zostały przez Katarzynę Brzozę-Kolorz, Dagmarę Głuszek-Szafraniec i Patrycję Szostok-Nowacką (2019, s. 112). Badaczki przeanalizowały obraz mediów i polityki w wybranych polskich tygodnikach opinii w okresie całego 2015 roku. Jak konkludują autorki, przeprowadzone badania empiryczne:

(...) pozwalają na stwierdzenie, że redakcje analizowanych tytułów [„Do Rzeczy”, „Newsweek Polska”, „Polityka”, „Wprost” - przyp. M.B.] niewątpliwie posiadają swoje preferencje polityczne, jednak nie wyrażają ich wprost poprzez jednoznaczne faworyzowanie którejś z partii. Ideologiczne nastawienie widoczne jest nie tyle w aprobacie, co w wyrażanej krytyce wobec opcji przeciwnej do preferowanej. Szczególnej podstawy do takiego wnioskowania dostarczają wyniki potwierdzające zwrot polityk redakcyjnych w tym zakresie tuż po wyborach parlamentarnych 2015 roku.

Materiały publikowane na łamach „Newsweeka” w 2015 roku miały charakter zdecydowanie przeciwny względem PiS - zarówno gdy partia ta była w opozycji, jak i po wygranych przez nią wyborach (Brzoza-Kolorz, Głuszek-Szafraniec, Szostok-Nowacka, 2019, s. 113). Stronniczość tygodnika „Newsweek” w 2015 roku została potwierdzona przez Agnieszkę Śliwę (2016, s. 95), która za pomocą analizy zawartości przebadała wypowiedzi redaktora naczelnego tego magazynu - Tomasza Lisa. W skład korpusu weszły teksty, które ukazały się na łamach pisma w 52 numerach z 2015 roku. Jak wskazuje Śliwa (2016, s. 101) - teksty redaktora naczelnego w zdecydowanej większości zawierały wyraźną krytykę PiS.

Według Brzozy-Kolorz, Głuszek-Szafraniec i Szostok-Nowackiej (2019, s. 113114) „Do Rzeczy” stanowi wyraźne przeciwieństwo „Newsweeka”. Przekaz formułowany w 2015 roku na łamach „Do Rzeczy” miał charakter aprobujący PiS, 
a przeciwny wobec wszystkich pozostałych opcji politycznych. „Polityka”, mimo klarownie określonych preferencji, unikała prezentacji poglądów politycznych w sposób ostentacyjny. Oznaczało to względnie otwartą krytykę PiS z jednoczesnym brakiem wyraźnego chwalenia jakiegokolwiek innego aktora politycznego. Jednakże o przychylności „Polityki” wobec PO - a w mniejszym stopniu wspieraniu również PSL - świadczył brak jednoznacznej, wyraźnej krytyki tych dwóch formacji.

Materiały ukazujące się w 2015 roku na łamach tygodnika „Wprost” miały charakter względnie wyważony (Brzoza-Kolorz, Głuszek-Szafraniec, Szostok-Nowacka, 2019, s. 113). Było to swego rodzaju:

(...) balansowanie między krytyką a aprobatą, przy czym ostatecznie widoczne (choć nie bardzo wyraźnie) było przechylenie w stronę Prawa i Sprawiedliwości, która to partia była chwalona na łamach tygodnika nieco częściej, zdecydowanie zaś od innych rzadziej była krytykowana.

O swoistych próbach utrzymywania względnie neutralnego tonu przez redakcję tygodnika „Wprost” podczas wyborów prezydenckich w 2015 roku pisze Rafał Klepka (2016, s. 149). Badacz przeprowadził analizę zawartości trzech tygodników opinii („Newsweeka”, „Polityki” i „Wprost”), które ukazywały się w okresie sześciu tygodni poprzedzających pierwszą turę wyborów prezydenckich. $\mathrm{Z}$ badań wynika, że najprzychylniejsza Bronisławowi Komorowskiemu była „Polityka”, natomiast zdaniem Klepki (2016, s. 146-147) ówczesny kandydat PiS - Andrzej Duda:

(...) tylko w jednym materiale umieszczonym w tygodniku „Wprost” został przedstawiony w pozytywnym świetle. W przypadku obydwu pozostałych tygodników w żadnym numerze nie udało się odnaleźć materiałów pozytywnie wypowiadających się na temat kandydatury Andrzeja Dudy. W tygodniku „Newsweek” poza jedną neutralną wypowiedzią, wszystkie miały jednoznacznie krytyczny wydźwięk. W „Polityce” opinii negatywnych było wprawdzie więcej, jednak poza nimi występowały także publikacje o charakterze neutralnym. W tygodniku „Wprost” poza jednym materiałem pozytywnym występują także publikacje neutralne i negatywne.

Przy analizie poziomu stronniczości tygodnika „Polityka” warte przywołania są wyniki badań Mariusza Kolczyńskiego (2017, s. 36), który przeprowadził analizę zawartości przekazów poświęconych kampaniom wyborczym oraz wyborom prezydenckim, opublikowanych na łamach „Polityki” w okresie od 1 listopada 2014 do 31 października 2015 roku. W przeanalizowanym materiale odnotowano 103 bezpośrednie odniesienia do działań lub propozycji programowych podmiotów uczestniczących w wyborach 2015 roku. Jak wskazuje Kolczyński (2017, s. 44-45) przekaz stronniczy występował szczególnie wobec PiS i kandydata tej partii na prezydenta:

W przypadku „lidera” (PiS / A. Duda) ogólny wydźwięk publikacji można zaklasyfikować jako: negatywny $-77,5 \%$ odniesień, pozytywny $-2 \%$, neutralny/mieszany $-20,4 \%$. Dla 
porównania, w przypadku PO: wydźwięk pozytywny - 73,9\%, negatywny - 8,7\%, neutralny/mieszany $-17,4 \%$.

Wyraźna stronniczość ideologiczna i polityczna czterech z sześciu analizowanych tygodników opinii została dowiedziona przez Laurę Polkowską na łamach monografii o intrygującym tytule Wartości i antywartości $w$ tygodnikach opinii (2018). Badaczka przeanalizowała teksty opublikowane na łamach „Polityki”, „Newsweeka”, „Do Rzeczy” oraz „Sieci” w dwóch szczegółowo wyznaczonych okresach - od 1 lipca 2013 do 30 czerwca 2014 roku oraz od 1 lipca 2016 do 30 czerwca 2017 roku. W okresie pierwszym władzę sprawowała koalicja PO-PSL, podczas gdy okres drugi stanowił półmetek pierwszej kadencji rządów Zjednoczonej Prawicy (Polkowska, 2018, s. 25).

Polkowska (2018, s. 334-335) zwraca uwagę na wyraźną radykalizację dyskursu liberalnego na łamach „Polityki” i „Newsweek Polska” w drugim okresie badawczym - czyli po alternacji władzy w 2015 roku. Nazwy wartości pozytywnych, takich jak „wolność”, „polskość”, „tolerancja”, coraz częściej na łamach tychże tytułów były wykorzystywane w celu dyskredytacji oponentów ideologicznych, medialnych lub politycznych (telewizji publicznej, prasy konserwatywnej i PiS). Tymczasem dla tożsamościowej prasy konserwatywnej („Do Rzeczy”, „Sieci”) analogiczny wyznacznik pozostawał na stałym, wysokim poziomie w dwóch okresach badawczych.

Na temat sympatii i antypatii politycznych wymienionych tygodników liberalnych pisze Tomasz Mielczarek (2018). W jego opinii „Newsweek”, kierowany przez Tomasza Lisa, po objęciu władzy przez PiS został przekształcony - jak akcentuje Mielczarek (2018, s. 174) - w „swoisty głos parlamentarnej opozycji”. Przejawiało się to częstymi atakami personalnymi na prezydenta, premiera i Jarosława Kaczyńskiego, jak również podejmowaniem i nagłaśnianiem tematów trudnych z punktu widzenia rządzących. Podobny mechanizm krytyki wobec PiS działał w przypadku tygodnika „Polityka”. Krytyka publicznych działań tej partii miała bardzo szeroki charakter, obejmując m.in. analizę osobowości szefa tej formacji (Mielczarek, 2018, s. 113).

Ostatnim podmiotem analizowanym w tej części opracowania jest „Gazeta Polska” („GP”). W podrozdziale dotyczącym dzienników przedstawiono wyniki badań dotyczące stronniczości „GPC”, stanowiącej codzienne rozszerzenie „GP”. Cechy dyskursu obecnego na łamach tych dwóch tytułów mają charakter zbieżny. Jak wskazuje Grzegorz Marchwiński (2012, s. 196), autorzy piszący dla „GP” reprezentują światopogląd budowany w charakterze odpowiedzi na pozostałe światopoglądy obecne w sferze publicznej - przede wszystkim reprezentowane przez środowisko "GW".

Na łamach „GP” pod względem przedmiotowym od wielu lat krytykowano lewicową, liberalną wizję świata społecznego (Kozielski, 2014, s. 277). Pod względem podmiotowym atakowano politycznych i medialnych przeciwników PiS. Jak wskazują Paweł Kozielski i Ewelina Gutowska-Kozielska (2018, s. 72), linia programowa 
„GP” wyraźnie koresponduje z programem i narracją tejże partii. Relacja swoistej zbieżności narracyjnej zachodziła jeszcze na długo przed rokiem 2015, natomiast kamieniem milowym okazał się dramat katastrofy smoleńskiej w kwietniu 2010 roku. Od tego czasu współpraca części środowisk związanych z PiS i redakcją „GP” uległa zacieśnieniu.

W obrębie przestrzeni dyskursywnej i organizacyjnej tygodnika zaczęły powstawać początkowo dziesiątki, a następnie setki lokalnych klubów „GP” (Ślarzyński, 2018). Kluby te, wraz z wieloma innymi prawicowymi i konserwatywnymi środowiskami (zorganizowanymi m.in. wokół redakcji „Naszego Dziennika” i wspólnoty Radia Maryja), złożyły się na względnie spójny ideologicznie podsystem opozycyjny wobec rządzącej w latach 2007-2015 koalicji PO-PSL. Poszczególne ogniwa podsystemu zyskały nawet w 2012 roku afirmatywne miano wysp , archipelagu polskości”. Autorem metaforycznego określenia był Andrzej Zybertowicz - od 2015 roku pełniący funkcję doradcy społecznego prezydenta Andrzeja Dudy.

Reasumując, w segmencie prasy opinii aż pięć na sześć analizowanych podmiotów cechuje się wyraźną, długofalową stronniczością polityczną. Zarówno dla trzech analizowanych tygodników konserwatywnych („Do Rzeczy”, „Sieci” i „GP”), jak i dla dwóch relewantnych przedstawicieli prasy opinii reprezentujących światopogląd liberalny („Newsweek Polska” i „Polityka”) wykazano wyraźne sympatie i antypatie polityczne. Jedynie tygodnik „Wprost” nie wpisuje się jednoznacznie $\mathrm{w}$ charakterystykę medium długofalowo stronniczego w jednym wektorze.

\section{Podstawowe kierunki stronniczości w całodobowych stacjach informacyjnych}

O strukturalnym charakterze problemu, tym razem w zakresie mediów elektronicznych, świadczą wyniki monitoringu mediów przeprowadzonego przez ODIHR OBWE w ostatnich dwóch tygodniach kampanii wyborczej przed wyborami parlamentarnymi (2019). W raporcie (ODIHR OBWE, 2020, s. 21) na pierwszym miejscu umieszczono problem wyraźnej stronniczości mediów publicznych:

(...) wbrew przepisom prawa i mandatowi publicznemu serwisy informacyjne TVP1 i TVP Info prezentowały wyraźną niechęć wobec kandydatów KO i PSL. Dziennikarze często określali kandydatów opozycyjnych mianem „żałosnych”, „niekompetentnych” czy „kłamliwych”. W monitorowanym okresie odpowiednio 40\% i 6\% materiałów politycznych w TVP1 oraz 40\% i 4\% w TVP Info było poświęconych KO i PSL, a ich wydźwięk był w przeważającej mierze negatywny. PiS i rząd mieli natomiast odpowiednio $17 \%$ i $24 \%$ czasu antenowego w TVP1 oraz 25\% i 18\% w TVP Info, a ton poświęconych im materiałów był zazwyczaj pozytywny.

Stosowanie „podwójnych standardów” podczas prezentowania polityków różnych opcji politycznych nie dotyczyło jedynie przekazu obecnego na antenie TVP. 
Stronniczość w sposobach relacjonowania kampanii pojawiała się również w mediach prywatnych (TVN i TVN24) (Raport ODIHR OBWE, 2020, s. 22):

Chociaż media prywatne na ogół wykazywały się mniejszą stronniczością, audycje informacyjne TVN i TVN24 zawierały zazwyczaj krytyczne wypowiedzi na temat rządu i PiS, którym poświęcono odpowiednio 32\% i 30\% czasu antenowego w TVN oraz $29 \%$ i $23 \%$ w TVN24. Te same stacje poświęciły KO 18\% i 20\% czasu antenowego, przy czym materiały na temat tego ugrupowania politycznego były w przeważającej mierze neutralne i pozytywne w TVN, a w TVN24 - bardziej wyważone.

Autorzy raportu (ODIHR OBWE, 2020, s. 18) zwrócili uwagę na sposoby finansowania mediów - jako na istotne uwarunkowanie przyjmowanej linii redakcyjnej. Kwestia ta ma ogromne znaczenie, szczególnie w kontekście rynku reklamowego, komercjalizacji i negatywnych mechanizmów występujących w okołomedialnym partnerstwie publiczno-prywatnym:

(...) rynek reklam zapewnia głównym mediom pewien stopień stabilności ekonomicznej. Wielu rozmówców ODIHR uważało jednak, że wybiórczość w zlecaniu płatnych reklam przez instytucje państwowe i spółki skarbu państwa była narzędziem wpływania na politykę redakcyjną w sposób mający sprzyjać rządowi.

W procesie analitycznym, mającym na celu weryfikację hipotezy, postanowiono przyjrzeć się poziomom udziału w rynku trzech głównych całodobowych stacji informacyjnych, które zostały częściowo omówione pod kątem poziomu relewantności i sposobów prezentowania informacji. W tabeli 2 zaprezentowanych zostało 17 najpopularniejszych kanałów telewizyjnych wraz ze wskazaniem poziomu i dynamiki wskaźnika SHR (oznacza on odsetek osób, które w danym czasie oglądały telewizję lub były widzami określonego programu).

Tabela 2. Najpopularniejsze kanały telewizyjne w latach 2018-2019

\begin{tabular}{|l|c|c|c|}
\hline \multirow{2}{*}{ Wirtualnemedia.pl } & \multicolumn{2}{c|}{ Wszyscy 4+ } & \multirow{2}{*}{ Dynamika } \\
\hline \multirow{2}{*}{ Stacja } & $\mathbf{0 1 . 0 1 - 1 8 . 1 2 . 2 0 1 8}$ & $\mathbf{0 1 . 0 1 - 1 8 . 1 2 . 2 0 1 9}$ & \\
\cline { 2 - 4 } & SHR \% & SHR \% & $\%$ \\
\hline \multirow{2}{*}{ Polsat } & $10,249 \%$ & $9,897 \%$ & $\mathbf{- 3 , 4 3 \%}$ \\
\hline TVP1 & $9,743 \%$ & $9,697 \%$ & $\mathbf{- 0 , 4 7 \%}$ \\
\hline TVN & $9,435 \%$ & $8,514 \%$ & $\mathbf{- 9 , 7 6 \%}$ \\
\hline TVP2 & $8,160 \%$ & $8,304 \%$ & $\mathbf{1 , 7 6 \%}$ \\
\hline TVN24 & $4,166 \%$ & $4,506 \%$ & $\mathbf{8 , 1 6 \%}$ \\
\hline TV4 pl & $4,183 \%$ & $3,733 \%$ & $\mathbf{- 1 0 , 7 6 \%}$ \\
\hline TVP Info & $3,441 \%$ & $3,660 \%$ & $\mathbf{6 , 3 6 \%}$ \\
\hline
\end{tabular}




\begin{tabular}{|l|c|c|c|}
\hline TV PULS & $3,407 \%$ & $3,497 \%$ & $\mathbf{2 , 6 4 \%}$ \\
\hline TVN7 & $3,247 \%$ & $3,200 \%$ & $-\mathbf{1 , 4 5} \%$ \\
\hline TTV & $2,130 \%$ & $2,229 \%$ & $\mathbf{4 , 6 5 \%}$ \\
\hline Puls 2 & $1,876 \%$ & $1,911 \%$ & $\mathbf{1 , 8 7 \%}$ \\
\hline TV6 & $1,443 \%$ & $1,703 \%$ & $\mathbf{1 8 , 0 2} \%$ \\
\hline Polsat 2 inf & $1,531 \%$ & $1,538 \%$ & $\mathbf{0 , 4 6} \%$ \\
\hline TVP Seriale & $1,411 \%$ & $1,406 \%$ & $\mathbf{- 0 , 3 5 \%}$ \\
\hline TVP ABC & $1,390 \%$ & $1,265 \%$ & $\mathbf{- 6 , 8 3} \%$ \\
\hline TVP Sport & $0,972 \%$ & $1,261 \%$ & $\mathbf{2 9 , 7 3 \%}$ \\
\hline Polsat News & $1,123 \%$ & $1,125 \%$ & $\mathbf{0 , 1 8} \%$ \\
\hline
\end{tabular}

Źródło: https://www.wirtualnemedia.pl/artykul/ogladalnosc-telewizji-2019-rok-polsat-liderem-tvp2wzrost (dostęp: 26.05.2020).

Zaprezentowane powyżej dane wydają się niezwykle istotne z punktu widzenia prowadzonego wywodu o charakterze analitycznym. Warto zwrócić uwagę, że TVN24 zajmuje w tym zestawieniu 5. miejsce z przyrostem dynamiki na poziomie 8,16 punktu procentowego. Dwa miejsca niżej w rankingu znajduje się TVP Info, które rok do roku również odnotowuje przyrost dynamiki, jednak na nieco niższym poziomie: 6,36 punktu procentowego. Polsat News z kolei zajmuje 17. miejsce (ostatnie pośród prezentowanych stacji) z praktycznie zerowym przyrostem dynamiki (0,18 punktu procentowego). Ilustruje to, że pośród całodobowych stacji TV o charakterze wyłącznie informacyjnym znaczący przyrost odnotowują dwie pierwsze spośród analizowanych. Tendencja ta znajduje potwierdzenie również dla kohorty wiekowej 16-49 (tab. 3).

Tabela 3. Najpopularniejsze kanały telewizyjne w latach 2018-2019 w grupie wiekowej 16-49

\begin{tabular}{|l|c|c|c|}
\hline \multirow{2}{*}{ Wirtualnemedia.pl } & \multicolumn{2}{|c|}{ Wszyscy 16-49 } & \multirow{2}{*}{ Dynamika } \\
\hline \multirow{2}{*}{ Stacja } & $\mathbf{0 1 . 0 1 - 1 8 . 1 2 . 2 0 1 8}$ & $\mathbf{0 1 . 0 1 - 8 . 1 2 . 2 0 1 9}$ & \\
\cline { 2 - 4 } & SHR \% & SHR \% & $\%$ \\
\hline \multirow{2}{*}{ TVN } & $12,276 \%$ & $11,151 \%$ & $\mathbf{- 9 , 1 6 \%}$ \\
\hline Polsat & $11,401 \%$ & $11,057 \%$ & $\mathbf{- 3 , 0 2} \%$ \\
\hline TVP2 & $6,863 \%$ & $7,141 \%$ & $\mathbf{4 , 0 5} \%$ \\
\hline
\end{tabular}




\begin{tabular}{|c|c|c|c|}
\hline TVP1 & $6,713 \%$ & $6,269 \%$ & $-6,61 \%$ \\
\hline TV PULS & $3,625 \%$ & $3,801 \%$ & $4,86 \%$ \\
\hline TVN7 & $3,377 \%$ & $3,647 \%$ & $8,00 \%$ \\
\hline TV4 pl & $3,897 \%$ & $3,511 \%$ & $-9,91 \%$ \\
\hline TTV & $2,911 \%$ & $3,339 \%$ & $14,70 \%$ \\
\hline TVN24 & $2,331 \%$ & $2,472 \%$ & $6,05 \%$ \\
\hline Puls 2 & $2,082 \%$ & $2,127 \%$ & $2,16 \%$ \\
\hline TV6 & $1,488 \%$ & $1,644 \%$ & $10,48 \%$ \\
\hline TVP Info & $1,273 \%$ & $1,574 \%$ & $23,64 \%$ \\
\hline TVP Seriale & $1,577 \%$ & $1,573 \%$ & $-0,25 \%$ \\
\hline TVP ABC & $1,498 \%$ & $1,377 \%$ & $-8,08 \%$ \\
\hline Polsat 2 inf & $1,373 \%$ & $1,279 \%$ & $-6,85 \%$ \\
\hline TVP Sport & $0,924 \%$ & $1,098 \%$ & $18,83 \%$ \\
\hline Super Polsat & $1,046 \%$ & $1,096 \%$ & $4,78 \%$ \\
\hline Polo TV & $0,933 \%$ & $0,998 \%$ & $6,97 \%$ \\
\hline TVN Turbo & $1,089 \%$ & $0,975 \%$ & $-10,47 \%$ \\
\hline Stopklatka & $0,903 \%$ & $0,951 \%$ & $5,32 \%$ \\
\hline TVN Style & $0,963 \%$ & $0,891 \%$ & $-7,48 \%$ \\
\hline Fokus TV & $0,895 \%$ & $0,865 \%$ & $-3,35 \%$ \\
\hline ATM Rozrywka & $0,850 \%$ & $0,825 \%$ & $-2,94 \%$ \\
\hline Polsat News & $0,702 \%$ & $0,730 \%$ & $3,99 \%$ \\
\hline
\end{tabular}

Źródło: https://www.wirtualnemedia.pl/artykul/ogladalnosc-telewizji-2019-rok-polsat-liderem-tvp2wzrost (dostęp: 26.05.2020).

Strategia biznesowa Polsat News, jaką przyjął najprawdopodobniej Zygmunt Solorz, polegająca na wyważonym przekazie i niesprzyjaniu bezpośrednim żadnej z dwóch głównych opcji politycznych w Polsce (Zjednoczona Prawica vs Platforma/Koalicja Obywatelska), skorelowana jest z najmniejszą dynamiką wzrostu udziału w rynku w porównaniu $\mathrm{z}$ dwiema konkurencyjnymi stacjami (TVP Info 
i TVN24). Jest to dostrzegalne szczególnie w grupie wszystkich odbiorców (4+), choć podobny trend występuje także dla grupy wiekowej 16-49.

Powyższą obserwację należało zweryfikować w raportach (źródłach) mających sprawdzać poziom stronniczości przekazów medialnych w Polsce. Ich analiza powinna pozwolić na wychwycenie istotnych korelacji, związanych $-\mathrm{z}$ jednej strony - ze znaczącą dynamiką wzrostu udziału w rynku (TVN24 i TVP Info), a z drugiej z wyraźną stagnacją (Polsat News). Autorzy, dokonując starannej krytyki źródeł, napotkali jednak na dość istotny problem metodologiczny - problem związany $\mathrm{z}$ występowaniem ryzyka stronniczości raportów mających za zadanie badać poziom stronniczości (sic!).

Hanna Karp (2017) na zlecenie KRRiT przeprowadziła analizę stronniczości sposobów relacjonowania kryzysu politycznego, który miał miejsce w polskim Sejmie w dniach 16-18 grudnia 2016 roku. Prześledziła kolejno pojawiające się narracje we wszystkich trzech stacjach. TVN24 określony został przez Karp (2017, s. 7-27) za pomocą następujących sformułowań:

(...) sugerowanie zaistnienia rządów autokratycznych, w kraju i państwie znajdującym się na drodze do systemu autorytarnego (...);

stałe elementy „narracji dyktatury”, sugerujące, iż opozycja pozbawiona jest praw, a Polska zamienia się w kraj, w którym następuje systemowe łamanie demokracji (...);

antena telewizyjna przekształca się w pas transmisyjny jednej strony sporu, sugerując także politykom, z którymi sympatyzuje, w pytaniach z tezą własne interpretacje.

W odniesieniu do stacji Polsat News - Karp (2017, s. 28-34) publikuje m.in. następujące wnioski:

(...) relacje z sytuacji zagrożenia i sytuacji niebezpiecznych (...);

nieoczekiwane uspokojenie, informacje tonujące narrację dramatyzmu (...);

dominują goście, komentatorzy, eksperci, politycy (...);

w studio goście dziennikarze, medioznawcy, politolodzy, od czasu do czasu połączenie $\mathrm{z}$ reporterem pod Sejmem w czasie rzeczywistym.

Z kolei TVP Info zostało określone następującymi cytatami:

zróżnicowane pasmo komentarzy (...);

wyczerpująca informacja o pracy dziennikarzy w Parlamencie Europejskim (...);

stały, pełny przekaz informacyjny o sytuacji politycznej (...);

pluralizm polityczny, obecna strona rządowa i opozycyjna (...);

podejmowanie wydarzeń przemilczanych przez innych nadawców (Karp, 2017, s. 44-55).

Z przytoczonych fragmentów (dobranych reprezentatywnie) wynika, że stacja prywatna TVN24 nie zachowywała obiektywizmu w relacjonowaniu niecodziennych wydarzeń w Sejmie w grudniu 2016 roku, w przeciwieństwie do TVP Info nadawcy publicznego, który miał wykazać się „,wyjątkowym” przestrzeganiem standardów etyki dziennikarskiej. Pod względem poziomu rzetelności i obiektywizmu 
pomiędzy TVN24 i TVP Info znalazł się Polsat News, wobec którego wnioski autorki dotyczące poziomu stronniczości miały charakter bardziej stonowany.

Jak już zauważono, zdyscyplinowana metodologicznie analiza (zwłaszcza ta o charakterze metapoziomowym) wymaga krytycznego podejścia do wszelkich źródeł. Przedmiotem konstruktywnej krytyki powinien stać się zatem i raport autorstwa Hanny Karp. Został on przygotowany na zlecenie KRRiT w 2017 roku. Próba spojrzenia na dokument $\mathrm{z}$ metapoziomu analitycznego, tzn. przez uwzględnienie jego instytucjonalno-politycznych kontekstów, prowadzi do konstatacji o ryzyku wystąpienia stronniczości w prowadzonych przez Karp ${ }^{10}$ analizach. KRRiT jest organem, którego skład w większości został powołany przez obecny obóz rządzący (obóz Zjednoczonej Prawicy) i którego kierownictwo miało wpływ na powołanie kierownictwa Telewizji Publicznej (zanim te kompetencje przejęła Rada Mediów Narodowych). KRRiT, zlecając zatem analizę, stoi w obliczu swoistego konfliktu interesów, gdyż ewentualne stwierdzenie nieprawidłowości dziennikarskich w przekazie stacji TVP Info byłoby potwierdzeniem niewłaściwych decyzji programowo-personalnych ze strony obozu rządzącego, który powołał samą KRRiT.

Rada Języka Polskiego, wypełniając obowiązek wynikający z art. 12 ust. 2 Ustawy o języku polskim, 14 marca 2019 roku złożyła Sprawozdanie o stanie ochrony języka polskiego za lata 2016-2017. Język informacji politycznej. Autorem szczegółowego opracowania jest prof. dr hab. Andrzej Markowski (2019, s. 7). Jego ustalenia w odniesieniu do TVP są jednoznaczne:

Wizja świata prezentowanego w paskach „Wiadomości” TVP 1 jest jednostronna, a jej osią aksjologiczną jest w większości przypadków opozycja: „obecna władza” - „ci, którzy jej nie popierają" - działania rządu i partii rządzącej są przedstawiane w sposób pozytywny, podczas gdy działania partii opozycyjnych, ruchów obywatelskich nieakceptujących decyzji rządu czy instytucji Unii Europejskiej zwykle są oceniane negatywnie.

Analiza Markowskiego dotyczyła tzw. pasków TVP, pojawiających się podczas programu Wiadomości. Z powyższego cytatu wynika jednoznacznie, że Telewizja Publiczna w swoim głównym programie informacyjnym stosowała przede wszystkim działania mające na celu chwalenie obecnej władzy i dyskredytację opozycji. W przytoczonym dokumencie nie znajdujemy analiz dotyczących przekazów formułowanych przez stacje prywatne (Polsat News czy TVN24). Wynika to z ustawowego obowiązku raportowania o medium publicznym. Jednakże z punktu widzenia analizy o charakterze medioznawczym brak analiz dotyczących prywatnych nadawców, przygotowanych według tej samej metodologii, utrudnia porównanie poziomów stronniczości języka informacji politycznej.

10 Wartym nadmienienia jest fakt, iż w kwietniu 2019 roku Hanna Karp nawiązała stałą współpracę publicystyczną z tygodnikiem „Sieci”, którego bliskie korelacje narracyjne z PiS wykazano w poprzednim podrozdziale. Szerzej: https://www.wirtualnemedia.pl/artykul/hanna-karppublicystka-tygodnika-sieci (dostęp: 25.05.2020). 
Warto zwrócić uwagę na raport przygotowany przez badaczy z Instytutu Dziennikarstwa i Komunikacji Społecznej Uniwersytetu Papieskiego Jana Pawła II w Krakowie, który objął 168 godzin programu TVP Info nadawanego od 4 do 10 czerwca 2018 roku. Kluczowy wniosek, jaki formułują autorzy raportu (Drożdż i in., 2019, s. 21), jest następujący:

Na poziomie informacji o wydarzeniach przekaz TVP Info spełnia standardy przekazu prawdziwego, natomiast $\mathrm{w}$ ich doborze, jak i narracji nacechowany jest pozytywnym nastawieniem wobec działań koalicji rządzącej, co należy uznać za przejaw opinii równoważącej subiektywne preferencje w całościowym przekazie telewizyjnym w Polsce. Ta sytuacja powinna być przejściowa do czasu, kiedy tę funkcję gwarantującą realny pluralizm przejmą inne kanały telewizji komercyjnych i prywatnych.

Powyższy wniosek, z jednej strony, charakteryzuje się krytyką względem TVP Info, a z drugiej - raczej asekuracyjnym obudowaniem tej narracji, sugerującym, że „informacje i opinie TVP Info w połączeniu $\mathrm{z}$ informacjami innych telewizji komercyjnych dają realną możliwość dotarcia przez odbiorców-obywateli do zobiektywizowanego obrazu rzeczywistości, reprezentatywnego dla poglądów wszystkich obywateli" (Drożdż i in., 2019, s. 25). Brakuje jednak pogłębionej analizy empirycznej, mogącej potwierdzać tę tezę. Podobnie jak w wypadku raportu Rady Języka Polskiego brakuje działań monitoringowych w odniesieniu do dwóch pozostałych całodobowych stacji informacyjnych (TVN24 i Polsat News).

W raporcie Instytutu Bronisława Komorowskiego (IBK) pt. Media publiczne 2015-2019: Studium upadku. I co dalej?, autorstwa Jana Dworaka, Magdy Jethon, Stanisława Jędrzejewskiego, Andrzeja Krajewskiego, Krzysztofa Lufta i Ludwika Tazowskiego (2019), zawarto kompleksową krytykę mediów publicznych, odnoszącą się zarówno do TVP, jak i do Polskiego Radia. Ze względu na zakres tematyczny niniejszego fragmentu artykułu przywołane zostaną wyłącznie cytaty dotyczące tej pierwszej. Można zatem znaleźć następujące treści:

(...) media publiczne stają się stroną w walce politycznej, przyczyniając się do rosnącej polaryzacji opinii publicznej, współtworząc środowisko, w którym nie ma miejsca na bezstronność (Dworak i in., 2019, s. 7).

Powyższy cytat nie jest oparty na analizie empirycznej, a jedynie na intuicyjnej ocenie autora (Jędrzejewskiego). Warto jednak zwrócić uwagę, że cytat ten w żadnym stopniu nie odnosi się do innych nadawców telewizyjnych, sugerując, że to wyłącznie media publiczne działają w ten sposób. Kolejny fragment raportu IBK (Dworak i in., 2019, s. 52) brzmi następująco:

W pierwszym roku „dobrej zmiany”, kiedy władzę w mediach publicznych przejmowali funkcjonariusze PiS i osoby przez nich wskazane, Towarzystwo Dziennikarskie publikowało listę dziennikarzy radia i telewizji, ofiar czystek [podkr. - M.B., F.G.].

Warto zwrócić uwagę na język, za pomocą którego sformułowane zostało to zdanie. Użycie sformułowań „funkcjonariusze PiS” oraz „ofiary czystek” kojarzy się 
z opisem praktyk stosowanych w totalitarnym państwie i charakterystyczne jest raczej dla języka publicystyki niż raportu mającego - co do zasady - na chłodno oceniać rzeczywistość, do której się odnosi. Semantyka jest tu o tyle istotna, że może u odbiorcy wytworzyć wstępne skojarzenia, przez których pryzmat będzie odbierać pozostałą część raportu.

Dokument IBK nie prezentuje empirycznej analizy zawartości, nie podaje informacji o poziomach stronniczości występujących w głównych telewizjach informacyjnych. Odnosi się bardzo krytycznie do mediów publicznych, jednak nie podejmuje w żaden sposób tematu nadawców prywatnych. Warto również - niejako z metapoziomu (podobnie jak w przypadku raportu Karp) - przyjrzeć się biografiom politycznym autorów raportu. Są to osoby związane głównie z szeroko rozumianym środowiskiem poprzedniej władzy - PO-PSL.

Tytułem przykładu - Jan Dworak jest byłym członkiem PO i byłym prezesem TVP w latach 2004-2006, który utracił stanowisko za rządów tzw. pierwszego PiS. W latach rządów PO-PSL (2010-2016) pełnił funkcję przewodniczącego KRRiT, którą utracił po ponownym objęciu władzy przez PiS. Drugi autor - Stanisław Jędrzejewski - był członkiem KRRiT powołanym w 2005 roku przez Aleksandra Kwaśniewskiego, odznaczonym Krzyżem Oficerskim Orderu Odrodzenia Polski (Krzyż Oficerski) przez prezydenta Bronisława Komorowskiego (2014). Trzeci autor - Andrzej Krajewski - to prezes Forum Obywatelskiego Rozwoju, czyli think tanku powołanego z inicjatywy Leszka Balcerowicza, w 2004 roku startujący bez powodzenia do Parlamentu Europejskiego z list PO, odznaczony Krzyżem Oficerskim przez prezydenta Bronisława Komorowskiego (2014).

Fragmentarycznie przywołane życiorysy autorów raportu IBK nie mają na celu podważania ich kompetencji lub jakiejkolwiek próby dyskredytacji, a jedynie wskazują na występowanie potencjalnego konfliktu interesów ${ }^{11}$ podczas przygotowywania raportów mających oceniać rzetelność mediów w warstwie politycznej. W tym przypadku chodzi o media publiczne, które wraz ze zmianą władzy zostały „przejęte" przez przeciwników politycznych środowiska związanego $\mathrm{z}$ autorami raportu. Podobnie jak w przypadku Karp trudno tu mówić o intersubiektywnej, ilościowej, bezstronnej analizie.

Andrzej Krajewski jest także autorem innego opracowania: Raportu $z$ monitoringu „Wiadomości” TVP w okresie kampanii wyborczej do Parlamentu Europejskiego 10-24 maja 2019 r. Publikacja została wydana wspólnie przez Fundację im. Stefana Batorego i Towarzystwo Dziennikarskie. Mimo szczegółowych analiz wykazujących stronniczość i manipulacje ze strony głównego programu informacyjnego TVP dokument (Krajewski i in., 2019, s. 15) nie pozwala na porównanie trzech głównych całodobowych stacji telewizyjnych.

Przywołane raporty miały umożliwić weryfikację postawionej hipotezy i pozwolić na wskazanie korelacji między poziomem dynamiki zwiększania udziału

11 Szerzej o konflikcie interesów w dziennikarstwie: Męcwal, 2010. 
w rynku całodobowych stacji telewizyjnych (TVN24 i TVP Info) a sposobem komunikacji politycznej w codziennych przekazach. Autorzy napotkali jednak problem natury metodologicznej. Krytyka źródeł mających wskazać poziomy stronniczości omawianych kanałów informacyjnych wykazała wysokie ryzyko subiektywizmu i - nomen omen - właśnie stronniczości samych raportów mających oceniać stronniczość. Ten metapoziomowy paradoks wynikał w znacznej mierze ze strukturalnych uwarunkowań ich powstania, takich jak:

- powiązania środowiskowe i polityczne autorów opracowań;

- prawne ograniczenia powstających dokumentów;

- niechęć lub brak możliwości przeprowadzenia kompleksowego monitoringu - za pomocą tej samej metodologii - co najmniej trzech głównych całodobowych stacji TV;

- konflikt interesów (potencjalny lub realny) autorów lub podmiotów opracowujących raporty.

Odmienną perspektywę analityczną prezentuje raport opracowany przez Instytut Dyskursu i Dialogu (Gołębiewski, 2018), w którym zastosowano tę samą metodologię w odniesieniu do wszystkich trzech stacji telewizyjnych. Jak piszą autorzy - Wydarzenia Polsatu cechowały się najmniejszą stronniczością w porównaniu z Faktami TVN i Wiadomościami TVP ${ }^{12}$. Tę wiedzę uzyskano za pomocą analizy wskaźników rzetelności i stronniczości. Z materiału zebranego i przeanalizowanego w raporcie wynika, iż w 2018 roku Wiadomości TVP stosowały szczególnie pozytywną prezentację wybranych podmiotów znacznie częściej niż pozostałe dwa programy informacyjne największych stacji telewizyjnych. Szczególnie pozytywna prezentacja dotyczyła głównie środowisk związanych z obozem Zjednoczonej Prawicy. Fakty TVN stosowały tego typu prezentację pozytywną znacznie rzadziej (w 12\% przypadków monitorowanych materiałów), a Wydarzenia Polsatu prawie w ogóle (4\% przypadków monitorowanych materiałów).

Raport INDID jest próbą porównania stronniczości narracji trzech głównych nadawców telewizyjnych według tej samej metodologii, która prowadzona jest na bieżąco przez wolontariuszy - koderów współpracujących z organizacją pozarządową. Nie można na tej podstawie wnioskować na temat całościowego przekazu całodobowych stacji TV, których jedynie niewielkim elementem są prezentowane wydania serwisów informacyjnych. Jeśli jednak przyjmiemy per analogiam założenie, że TVP Info oraz TVN24 są głównymi stacjami antagonizującymi spór polityczny w latach 2015-2020, a stacja Polsat News próbuje sytuować się pomiędzy nimi (niezależnie od powodów takiej strategii), wówczas dostrzegalne stają się wyraźne korelacje między poziomami wzrostu dynamiki udziału w rynku.

Innymi słowy, wydaje się względnie uzasadnionym twierdzenie, że im wyższy poziom stronniczości danej stacji $\mathrm{TV}$, tym wyższy poziom dynamiki wzrostu udziału w rynku. Co z kolei stanowi przyczynek do rozważań na temat nieopłacalności

12 Pod uwagę wzięto jedynie główne wydania serwisów informacyjnych. 
rzetelnego tworzenia materiałów medialnych i etycznego dziennikarstwa w dzisiejszej debacie publicznej w Polsce.

\section{Omówienie wyników i zakończenie}

Hipoteza wskazująca, iż w polskiej debacie publicznej, pośród spektrum podmiotów relewantnych medialnie, wyraźnie dominują takie, w których przekazie występuje wysoki stopień stronniczości politycznej, została w niniejszym tekście potwierdzona. Cztery na pięć analizowanych dzienników ogólnopolskich na przestrzeni ostatniej dekady cechowały się wyraźną stronniczością polityczną. W segmencie tygodników opinii aż pięć na sześć analizowanych podmiotów wykazywało wyraźną, długofalową stronniczość polityczną. Ponadto dwa z trzech podmiotów telewizyjnych, charakteryzujących się najwyższą dynamiką wzrostu udziału w rynku, prezentowały w ostatnich latach narrację: [1] wyraźnie prorządową i antyopozycyjną (TVP Info) oraz [2] proopozycyjną i antyrządową (TVN24). Owa „relewantna istotność” ilustruje w istocie siłę danego medium w zakresie jego pozycji rynkowej, generowania zysków, usytuowania symbolicznego i wpływu promieniującego na całą debatę publiczną (np. na zasadzie cytowania). Potwierdzenie tej hipotezy jest zatem pośrednim potwierdzeniem zjawiska, o którym mowa w tytule niniejszej pracy.

O ile jeszcze dekadę temu model polskiego systemu medialnego, a co za tym idzie - stan debaty publicznej - sytuowały się na swoistym rozdrożu między „spolaryzowanym pluralizmem" a modelem liberalnym (Dobek-Ostrowska, 2011a; 2011b, s. 49), o tyle Anno Domini 2020 jakościowy i strukturalny „stan” polskiej debaty publicznej wpisuje się coraz wyraźniej w model spolaryzowanego pluralizmu (Hallin, Mancini, 2007, s. 60-62), cechujący się - po pierwsze - wysokim stopniem interwencjonizmu państwowego w system medialny, zarówno $\mathrm{w}$ postaci dotowania silnych mediów publicznych, jak i strumieni finansowania wybranych mediów prywatnych za pomocą reklam spółek skarbu państwa; po drugie - silnymi tradycjami dziennikarstwa rzeczniczego (Fisher, 2016); oraz - po trzecie - silną polaryzacją medialną (Herrero i in., 2017, s. 4799-4800) z dominacją pluralizmu zewnętrznego. Można zaryzykować twierdzenie, że polska debata publiczna została doprowadzona do stanu, w którym bardziej opłacalnym - z rynkowego punktu widzenia - jest niestosowanie się do zasad etycznego dziennikarstwa niż rygorystyczne uwzględnianie ich w pracach redakcyjnych.

Wyniki przeprowadzonego badania wskazują na występowanie swoistego paradoksu opłacalności, na który autorzy niniejszego tekstu pragną zwrócić uwagę jako na zjawisko kluczowe dla zagadnienia zarządzania systemem medialnym oraz charakterystyczne dla ostatniej dekady funkcjonowania polskiego systemu medialno-politycznego w modelu spolaryzowanego pluralizmu. Jak się okazuje, model ten może wytwarzać warunki dla zaistnienia zjawiska paradoksu opłacalności 
i doprowadzania do skrajności w debacie publicznej. Jeśli zapanuje zgoda co do tezy wynikającej z niniejszego artykułu, to powinna ona stać się przyczynkiem do głębokiego przemyślenia i przedefiniowania stosowanych w obecnym systemie medialnym zachęt i bodźców dla rynku podmiotów medialnych w Polsce.

Podczas weryfikacji hipotezy zwrócono uwagę na problem metodologiczny związany z niewystarczającą liczbą rzetelnych, bezstronnych opracowań, bazujących na stałym monitoringu przekazów medialnych wedle tych samych kryteriów wobec różnych podmiotów. O ile jeszcze dostępne są opracowania naukowe, bazujące na danych empirycznych, o tyle w wypadku instytucji trzeciego sektora lub organizacji sektora publicznego brakuje opracowań niedotkniętych znacznym ryzykiem stronniczości. Wynika to ze strukturalnych uwarunkowań podmiotów zlecających analizy (np. IBK, KRRiT) oraz przyczynia się do intuicyjnego wyciągania wniosków przez ich autorów. Tym samym systemowa i systematyczna ocena jakości funkcjonowania podmiotów medialnych w Polsce staje się poważnym wyzwaniem. Wciąż aktualne pozostaje pytanie - who controls the controller?

\section{Bibliografia}

Bartoszek A. (2018). Kryzys debaty publicznej w polskiej demokracji a pop-polityka. „Przegląd Socjologiczny", 2(67), s. 65-91.

Bartoszewicz M. (2019). Tygodniki opinii - użteczny instrument marketingu politycznego? „Historia i Polityka”, 27(34), s. 57-69. DOI: 10.12775/HiP.2019.004.

Bobrowska E. (2012). Debata publiczna w świetle analizy dyskursu. Kryteria porównawcze. „Studia Socjologiczne”, 1(204), s. 39-55.

Brzoza K., Głuszek-Szafraniec D., Szostok P. (2017). Upolitycznienie przekazu prasowego w wybranych polskich tygodnikach opinii. Wstępny raport $z$ badań. „Political Preferences”, 16, s. 81-92. DOI: 10.6084/m9.figshare.5605678.

Brzoza-Kolorz K., Głuszek-Szafraniec D., Szostok-Nowacka P. (2019). „Cóż tam, panie, w polityce?" Czyli o wzajemnym postrzeganiu dziennikarzy i polityków w mediach. Katowice: Wydawnictwo Uniwersytetu Śląskiego.

Czyżewski M., Kowalski S., Piotrowski A. (2010). Rytualny chaos. Studium dyskursu publicznego. Warszawa: Wydawnictwa Akademickie i Profesjonalne.

Dobek-Ostrowska B. (2011a). Polski system medialny na rozdrożu. Media $w$ polityce, polityka $w$ mediach. Wrocław: Wydawnictwo Uniwersytetu Wrocławskiego.

Dobek-Ostrowska B. (2011b). Italianization (or Mediterraneanization) of the Polish Media System? [w:] D. Hallin, P. Mancini (eds.), Comparing Media Systems Beyond the Western World (Communication, Society and Politics). Cambridge: Cambridge University Press, s. 26-50. DOI:10.1017/CBO9781139005098.004.

Dobek-Ostrowska B. (2015). Między politologia i komunikologia. Razem czy osobno? Przypadek studiów porównawczych nad relacjami polityki i mediów w Europie Srodkowo-Wschodniej. „Politeja”, 5(36), s. 27-49. DOI: 10.12797/Politeja.12.2015.36.03.

Drożdż M. i in. (2019). Raport z monitoringu programu TVP INFO w dniach 4-10 czerwca 2018 roku dla potrzeb Rady Programowej TVP S.A. Kraków: Instytut Dziennikarstwa i Komunikacji Społecznej Uniwersytetu Papieskiego Jana Pawła II w Krakowie. 
Dworak J. i in. (2019). Raport. Media publiczne 2015-2019: Studium upadku. I co dalej? Warszawa: Instytut Bronisława Komorowskiego.

Fisher C. (2016). The Advocacy Continuum: Towards a Theory of Advocacy in Journalism. „Journalism", 17(6), s. 711-726.

Furman W. (2010). Paralelizm polityczny polskich tygodników opinii na przykładzie sporu o Lecha Watęse w 2008 roku. „Studia Medioznawcze”, 2(41), s. 49-57.

Gołębiewski F. (2018). Media pod lupą. Analiza przekazów medialnych z roku 2018. Toruń: Instytut Dyskursu i Dialogu.

Hallin D.C., Mancini P. (2007). Systemy medialne. Trzy modele mediów i polityki w ujęciu porównawczym. Kraków: Wydawnictwo Uniwersytetu Jagiellońskiego.

Herrero L.C. i in. (2017). Rethinking Hallin and Mancini Beyond the West: An Analysis of Media Systems in Central and Eastern Europe. „International Journal of Communication”, 11, s. 4797-4823.

Hordecki B., Piontek D. (2011). An Ideal of a Politician in Polish Tabloids "Super Express" and “Fakt. Daily”. „Środkowoeuropejskie Studia Polityczne”, 3, s. 47-60.

Kampka B. (2014). Debata publiczna. Warszawa: Oficyna Naukowa.

Kardaś J. (2018). Media obiektywne czy media stronnicze? Analiza wizerunku Platformy Obywatelskiej i Prawa i Sprawiedliwości w „Gazecie Wyborczej” podczas parlamentarnej kampanii w 2011 roku. „Rocznik Bibliologiczno-Prasoznawczy”, 10(21), s. 151-167.

Karp H. (2017). Analiza jakościowa przekazów w aspekcie przestrzegania przepisów w zakresie obowiązków programowych ustawy o radiofonii i telewizji oraz zobowiązań koncesyjnych stacji TVN24, POLSAT NEWS, TVP INFO i serwisów informacyjnych /Faktów/Wydarzeń/ Wiadomości z wydarzeń z polskiego Parlamentu i sprzed Sejmu w dniach 16-17-18 grudnia 2016 r. Raport na zlecenie KRRiT, http://www.krrit.gov.pl/Data/Files/_public/Portals/0/ raporty/raporty-z-monitoringow/raport.pdf (dostęp: 24.05.2020).

Karwat M. (2007). O złośliwej dyskredytacji. Manipulowanie wizerunkiem przeciwnika. Warszawa: Wydawnictwo Naukowe PWN.

Klepka R. (2016). Informowanie, krytyka i agitacja w wybranych tygodnikach opinii o kandydatach $w$ wyborach prezydenckich $w 2015$ roku [w:] H. Batorowska, Z. Kwiasowski (red.), Kultura informacyjna w ujęciu interdyscyplinarnym. Teoria i praktyka. Kraków: Uniwersytet Pedagogiczny im. Komisji Edukacji Narodowej w Krakowie, s. 140-152.

Klepka R. (2018a). Medialna stronniczość polityczna jako nowa forma cenzury: przypadek Wiadomości TVP [w:] Z. Romek, K. Kamińska-Chełminiak (red.), Cenzuro wróć? Mechanizmy ograniczania wolności słowa w Polsce po 1990 roku. Pułtusk: Oficyna Wydawnicza ASPRA-JR, s. 189-203.

Klepka R. (2018b). Medialna walka o dobra zmianę. Obraz wyborów parlamentarnych w 2015 roku w wybranych mediach. Kraków: Wydawnictwo Libron.

Kokot M., wyborcza.pl (2015). Czy Polska rozbiła Grupę Wyszehradzka?? Wyszehrad ma się dobrze, czy ma sięźle?, 24.09, https://wyborcza.pl/1,76842,18899120,czy-polska-rozbila-grupe-wyszehradzka-wyszehrad-ma-sie-dobrze.html (dostęp: 25.05.2020).

Kolczyński M. (2008). Strategie komunikowania politycznego. Katowice: Wydawnictwo Uniwersytetu Śląskiego.

Kolczyński M. (2017). Stronniczość mediów w bipolarnym środowisku politycznym. Tygodnik „Polityka” w kampaniach wyborczych 2015 roku. „Polityka i Społeczeństwo”, 1(15), s. 3347. DOI: 10.15584/polispol.2017.1.3.

Komunikat Zarządu Związku Kontroli i Dystrybucji Prasy o wysokości nakładów i dystrybucji tytułów kontrolowanych przez ZKDP w 2018 roku, Uchwała nr 25/2019 z dnia 5 września 2019 roku. 
Kozielski P. (2014). Pro-pornographic Sex Education as an Ailment of the Polish Republic: An Analysis of the Press Discourse of “Gazeta Polska”. „Ars Educandi”, 11, s. 269-278.

Kozielski P., Gutowska-Kozielska E. (2018). Fat Cats Brought Up on Fukuyama and Lyotard... or Post-modernity in “Gazeta Polska”. „Media - Business - Culture. Journalism and Social Communication", 5, s. 69-80.

Krajewski A. i in. (2019). Raport z monitoringu „Wiadomości” TVP w okresie kampanii wyborczej do Parlamentu Europejskiego 10-24 maja 2019 r. Warszawa: Towarzystwo Dziennikarskie, Fundacja im. Stefana Batorego.

Kurdupski M. (2020). Polsat i TVN liderami oglądalności w 2019 roku, TVP2 na plusie. „M jak miłość" i „Teleexpress” hitami. Wirtualne Media, 1.01, https://www.wirtualnemedia.pl/artykul/ogladalnosc-telewizji-2019-rok-polsat-liderem-tvp2-wzrost (dostęp: 24.05.2020).

Leśniczak R. (2019). Proeuropejskość czy eurosceptycyzm? Wizerunek Unii Europejskiej w kontekście kryzysu migracyjnego i uchodźczego. „Łódzkie Studia Teologiczne” 28(1), s. 115131.

Lisowska-Magdziarz M. (2013). Reprezentacje biedy i wykluczenia społecznego $w$ tabloidach i mediach głównego nurtu. „Środkowoeuropejskie Studia Polityczne”, 1, s. 33-53.

Marchwiński G. (2012). „Wsłuchać się w nieskończoną opowieść o Polsce”. Dyskurs smoleński „Gazety Polskiej”. „Sprawy Narodowościowe”, 40, s. 181-196.

Markowski A. (2019). Sprawozdanie o stanie ochrony języka polskiego za lata 2016-2017. Raport na zlecenie Sejmu RP, Druk nr 3324, Warszawa, 14 marca 2019 r.

Męcwal S. (2010). Conflicts of Interest in Journalism. Alocal Journalist in the Network of Conflicts of Interest [w:] Conference Proceedings of Conflict of Interest in Central and Eastern Europe: An International Conference at the Institute of Sociology, Nicolaus Copernicus University Toruń, Poland, 25-27 August 2010, http://www.coi.conference.umk.pl/texts/Sylwia_Mecfal.pdf (dostęp: 24.05.2020).

Mielczarek T. (2018). Tygodniki opinii w zmieniającej się rzeczywistości. Kraków: Universitas.

Najbardziej opiniotwórcze polskie media w 2018 roku. Instytut Monitorowania Mediów, Warszawa, styczeń 2019 r.

Nierenberg B. (2011). Zarządzanie mediami. Ujęcie systemowe. Kraków: Wydawnictwo Uniwersytetu Jagiellońskiego.

Obacz P. (2018). Analiza sytuacyjna polskiego życia politycznego i społeczeństwa. Kilka uwag na temat wielości źródeł władzy w Polsce [w:] A. Pytka, K. Maciąg (red.), Rozważania na temat kondycji polskiego społeczeństwa. Lublin: Wydawnictwo Naukowe Tygiel, s. 14-23.

Olechowska P. (2017). Stopień stronniczości polskich dzienników ogólnoinformacyjnych (wybrane wyznaczniki). „Political Preferences”, 16, s. 107-130.

Polkowska L. (2018). Wartości i antywartości w tygodnikach opinii. Analiza dyskursu z elementami lingwistyki kwantytatywnej. Warszawa: Wydawnictwo Naukowe UKSW.

Sanecka-Tyczyńska J. (2015). Ocena III Rzeczypospolitej - płaszczyzna polaryzacji współczesnej polskiej sceny politycznej. „Annales Universitatis Paedagogicae Cracoviensis. Studia Politologica”, XIV, s. 99-114.

Sprawozdanie końcowe z krótkoterminowej misji obserwacji wyborów ODIHR, Biuro Instytucji Demokratycznych i Praw Człowieka (ODIHR), Warszawa, 14 lutego 2020.

Ślarzyński M. (2018). Rola klubów „Gazety Polskiej” w sukcesie politycznym Prawa i Sprawiedliwości w 2015 roku. Aktorzy lokalni czy aktor ogólnokrajowej sfery publicznej III RP? „Przegląd Socjologiczny”, 2(67), s. 139-158, https://doi.org/10.26485/PS/2018/67.2/6.

Śliwa A. (2016). Publicystyka Tomasza Lisa nałamach „NewsweekPolska” w 2015 roku [w:] M. Dajnowicz, A. Miodowski (red.), Polityka i politycy w prasie XX i XXI wieku. Białystok: Wydawnictwo HUMANICA Instytut Studiów Kobiecych, s. 91-102. 
Tvn24.pl (2015). Kopacz: Możemy przyjąć więcej niż 2 tys. uchodźców. Zapraszam liderów partii na spotkanie, 8.09, https://tvn24.pl/polska/kopacz-ws-uchodzcow-mozemy-przyjac-wiecej-uchodzcow-ra575563-3311359 (dostęp: 25.05.2020).

Zybertowicz A. (2012). Archipelag polskości. „Teologia Polityczna”, 18.04, https://teologiapolityczna.pl/andrzej-zybertowicz-archipelag-polskosci (dostęp: 24.05.2020). 